\title{
OPTIMASI KOMPOSISI PASIR, FOAM AGENT DAN SUHU CURING PADA SINTESIS BETON RINGAN SELULAR GEOPOLIMER DENGAN PENDEKATAN METODE TAGUCHI
}

\author{
NDARU CANDRA SUKMANA ${ }^{1}$, EKY MASBUCHIN ${ }^{1}$, UFAFA ANGGARINI ${ }^{2 *}$ \\ ${ }^{1}$ Departemen Manajemen Rekayasa, Universitas Internasional Semen Indonesia \\ ${ }^{2}$ Departemen Teknik Kimia, Universitas Internasional Semen Indonesia \\ *Corresponding author: $ه$ ufafa.anggarini@uisi.ac.id
}

Naskah diterima : 15 Mei 2019. Disetujui: 13 Februari 2020

\begin{abstract}
ABSTRAK
Beton ringan geopolimer telah disintesis dengan abu layang kelas C (fly ash class C) sebagai sumber aluminosilikat dan penambahan foam agent sebagai agen pembentuk pori dengan metode CLC (Celular Lightweight Concrete). Sintesis geopolimer dalam penelitian ini dilakukan dengan pendekatan metode Taguchi, yaitu metode perbaikan produk dengan biaya dan sumber daya seminal mungkin. Faktor yang diamati dalam penelitian ini adalah rasio penambahan pasir, rasio foam agent, dan kondisi suhu curing. Metode ini dijalankan untuk mengidentifikasi faktor yang berpengaruh signifilkan terhadap kuat tekan geopolimer melalui analisis ANOVA dan menentukan level optimum dari setiap faktor yang berpengaruh dalam sintesis geopolimer melalui nilai Signal to Noise Ratio (SNR) dengan karakteristik larger is better. Hasil yang diperoleh menunjukkan bahwa faktor yang berpengaruh pada kuat tekan adalah faktor perbandingan volume antara foam terhadap campuran pasir dan pasta geopolimer. Komposisi optimum diperoleh dengan kombinasi rasio pasir tehadap pasta geopolimer sebesar 1:1, rasio foam terhadap pasir dan pasta sebesar 1:1 serta suhu curing sebesar $25{ }^{\circ} \mathrm{C}$ sehingga menghasilkan nilai kuat tekan rata-rata maksimum sebesar $63 \mathrm{~kg} / \mathrm{cm}^{2}$.
\end{abstract}

Kata kunci : abu layang, beton ringan geopolimer, metode taguchi, kuat tekan

\section{PENDAHULUAN}

Perkembangan sektor industri khususnya di Indonesia mengakibatkan konsumsi energi menjadi lebih besar. Darmawan (2015) menjelaskan bahwa peningkatan konsumsi energi di sektor industri pada tahun 2013 mencapai 428 juta SBM dengan penggunaan batubara sebanyak $42 \%$ dan meningkat pada tahun 2014 hingga 48\%. Pembakaran batubara menghasilkan limbah coal ash yang terdiri dari abu layang (fly ash) dan abu dasar (bottom ash) (Wijaya, 2014). Bhakti, Olivia, and Kamaldi (2015) menjelaskan bahwa limbah fly ash memiliki kandungan kapur dan silika yang dapat menghasilkan material dengan kemampuan mengikat saat terjadi reaksi kimia antara oksida silika dengan natrium hidroksida. Fly ash sendiri terdiri dari unsur utama yakni 19,35\% $\mathrm{Al}_{2} \mathrm{O}_{3}, 58,91 \% \mathrm{SiO}_{2}$ dan DOI : https://doi.org/10.25077/jrs.16.1.1-11.2020 
8,65\% $\mathrm{CaO}$. Kandungan utama pada fly ash tersebut telah memenuhi kriteria bahan yang bersifat semen/pozzolan (U. Anggarini, Sukmana, \& Prasetya, 2017). Adanya sifat pozzolan dan kandungan unsur aluminosilikat yang dimiliki fly ash tersebut juga menjadi suatu potensi untuk dijadikan sebagai bahan pembuatan geopolimer.

Di lain sisi, pertumbuhan konstruksi di Indonesia mengalami peningkatan yang cukup besar. Berdasarkan data pada tahun 2015, pertumbuhan pada sektor konstruksi mencapai $6,65 \%$ (Ramdani, 2015). Data Badan Pusat Statistik Nasional (BPS) menunjukkan pada indeks nilai konstruksi pada triwulan II di tahun 2016 sebesar 203,91 naik di tahun 2017 mencapai angka 224,50. Kenaikan tersebut dapat mempengaruhi tingkat kebutuhan material penyusun konstruksi yang ada. Semen portland sebagai bahan utama konstruksi saat ini, memiliki keunggulan kekuatan mekanik yang tinggi dan ketahanan terhadap berbagai kondisi. Namun demikian, emisi gas $\mathrm{CO}_{2}$ pada proses pembakaran bahan baku semen pada kiln dapat menyebabkan peningkatan efek rumah kaca. Berdasarkan hal tersebut, dibutuhkan suatu material yang memiliki kekuatan menyerupai semen portland namun tanpa menghasilkan gas buang $\mathrm{CO}_{2}$, salah satunya adalah geopolimer. Semen geopolimer disintesis dengan bahan yang mengandung mineral aluminasilikat dengan bantuan larutan alkali aktivator yang terdiri dari natrium silikat dan natrium hidroksida. Beberapa penelitian terkait geopolimer telah banyak dilaporkan sebagai material untuk aplikasi kekuatan mekanik tinggi. Tantangan dalam pengembangan geopolimer saat ini adalah untuk menciptakan struktur ringan pada geopolimer, namun dengan kekuatan yang masih memenuhi SNI untuk beton ringan.

Dalam penelitian ini efisiensi penggunaan material alternatif diupayakan sebagai diversifikasi bahan material konstruksi berupa beton ringan geopolimer dengan memanfaatkan bahan baku abu layang sebagai sumber silika dan aluminat. Sintesa beton ringan geopolimer menggunakan metode Aerated Concrete (AC) melalui sistem penambahan foam agent atau bisa disebut sebagai Celular Lightweight Concrete (CLC) (Narayan \& Ramamurthy, 2000) dengan mempertimbangkan pembentukan gelembung udara pada beton lebih seragam dan stabil. Optimasi beton ringan geopolimer didapatkan melalui perancangan eksperimen Taguchi. Metode Taguchi sendiri merupakan metode yang dilakukan dalam tiga tahapan perancangan terintegrasi, yakni perancangan sistem, perancangan parameter dan perancangan toleransi (Wuryandari, 2009).

\section{METODE}

\subsection{Alat dan Bahan}

Alat yang digunakan pada penelitian terdiri dari ayakan, neraca analitik, baskom, sekop semen, mixer, cetakan beton dimensi $5 \times 5 \times 5 \mathrm{~cm} 3$, foam generator, gelas ukur, pengaduk dan alat uji kuat tekan beton analog. Bahan penelitian terdiri dari limbah abu layang kelas $\mathrm{C}$ (fly ash class C), padatan $\mathrm{NaOH}$, aquadest, Natrium Silikat, agregat pasir dan foam agent. $\mathrm{Abu}$ layang yang digunakan dalam penelitian ini tergolong dalam kelas $\mathrm{C}$, dengan kandungan oksida CaO lebih dari 8\%berat (U. Anggarini \& Sukmana, 2018). Kandungan persentase oksida dalam abu layang yang digunakan sebagai bahan baku dalam penelitian ini diuji dengan instrumen XRF (X-Ray Fluoroscence) seperti tertera pada Tabel 1. Larutan $\mathrm{NaOH}$ sebagai aktivator dipersiapkan dengan melarutkan sejumlah padatan $\mathrm{NaOH}$ ke dalam aquadest hingga diperoleh larutan dengan konsentrasi $7 \mathrm{M}$ (U. Anggarini et al., 2017). Larutan $\mathrm{NaOH}$ selanjutnya diperam selama 24 jam untuk menghilangkan panas reaksi pelarutan $\mathrm{NaOH}$. Rasio $\mathrm{Si} / \mathrm{Al}$ dalam sintesis bata ringan geopolimer ditetapkan yaitu 4 (U. Anggarini \& Sukmana, 2018). Agregat pasir dalam penelitian ini digunakan sebagai pengisi 
atau agregat halus dengan karakteristik kehalusan butir dengan ukuran menembus ayakan 4,8 mm sesuai dengan SNI 03-1749-1990. Penyeragaman ukuran partikel pasir sebagai agregat halus dilakukan sebelum pembuatan beton ringan geopolimer.

Tabel 1. Komposisi kandungan oksida abu layang

\begin{tabular}{lccccc}
\hline Oksida & $\mathrm{SiO}_{2}$ & $\mathrm{Al}_{2} \mathrm{O}_{3}$ & $\mathrm{CaO}$ & $\mathrm{Fe}_{2} \mathrm{O}_{3}$ & $\mathrm{MgO}$ \\
\hline \%berat & 31.96 & 22.62 & 18.94 & 15.20 & 11.11 \\
\hline
\end{tabular}

\subsection{Diagram Alir Penelitian}

Tahapan penelitian penentuan komposisi optimum beton ringan geopolimer dengan pendekatan metode Taguchi seperti tertera pada Gambar 1.

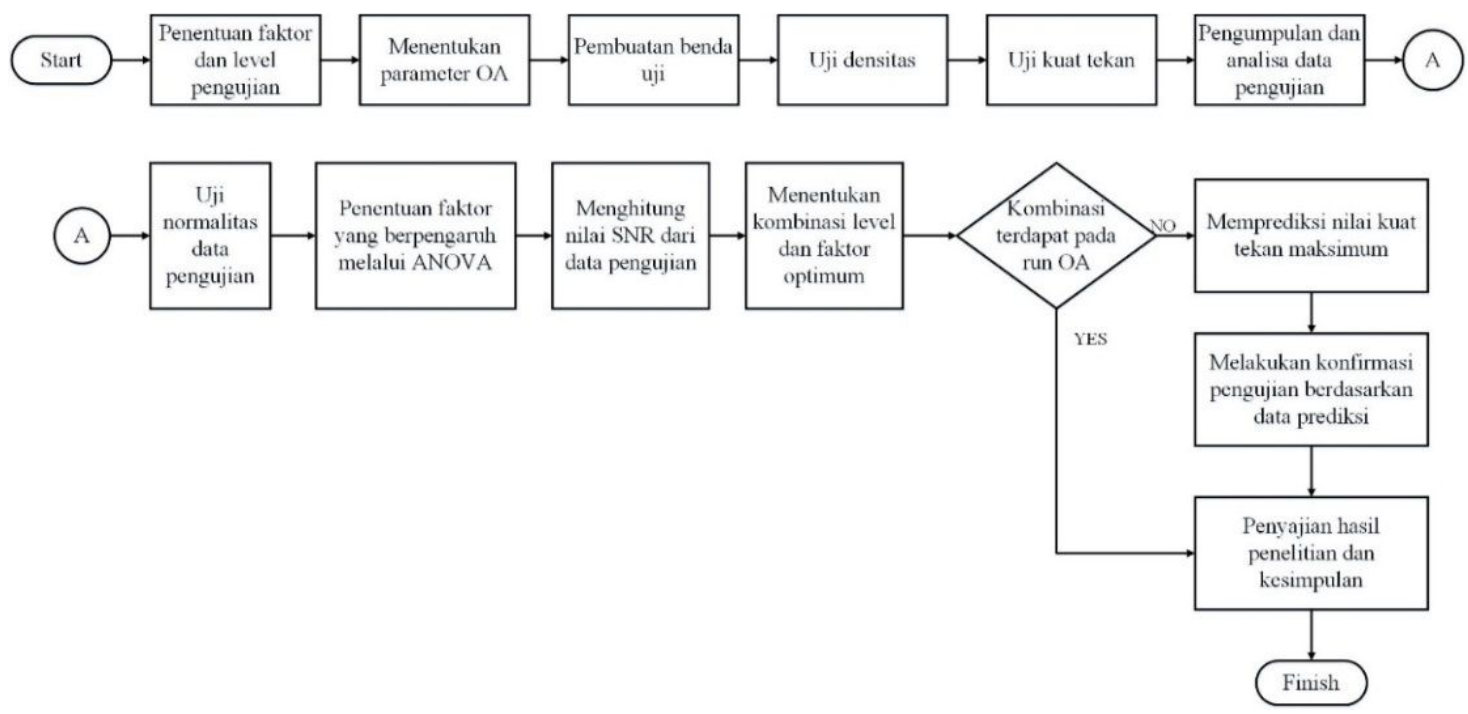

Gambar 1. Diagram Alir Penelitian

\subsection{Diagram Alir Penelitian}

Faktor yang digunakan pada penelitian yakni: perbandingan berat Pasir terhadap Pasta Geopolimer (A), perbandingan volume antara foam terhadap campuran pasir dan pasta geopolimer (B), dan Faktor temperatur curing (C).

Tabel 2. Faktor dan Level Pengujian

\begin{tabular}{cccc}
\hline \multirow{2}{*}{ Level } & \multicolumn{3}{c}{ Faktor } \\
\cline { 2 - 4 } & $\mathrm{A}$ & $\mathrm{B}$ & $\mathrm{C}$ \\
& $\left(\mathrm{W}_{\text {sand }} / \mathrm{W}_{\text {pasta }}\right)$ & $\left(\mathrm{V}_{\text {foam }} / \mathrm{V}_{\text {sand }+ \text { pasta }}\right)$ & Temperature $\left({ }^{\circ} \mathrm{C}\right)$ \\
\hline $\mathbf{1}$ & 1 & 1 & 25 \\
$\mathbf{2}$ & 1,5 & 2 & 60 \\
$\mathbf{3}$ & 2 & 3 & 100 \\
\hline Keterangan: $\mathrm{W}=$ berat $(\mathrm{gr}), \mathrm{V}=$ volume $(\mathrm{mL})$
\end{tabular}

\subsection{Diagram Alir Penelitian}

Parameter dari OA pada metode taguchi yang digunakan adalah menggunakan $\mathrm{L}_{9} 3^{3}$ dengan detil memiliki 9 variasi percobaan untuk 3 faktor dan 3 level. Masing-masing variasi percobaan dilakukan dengan pengulangan percobaan sebanyak 4 kali untuk mendapatkan kuat tekan rata-rata. 
Tabel 3. Variasi Pengujian $\mathrm{OA} \mathrm{L}_{9} 3^{3}$

\begin{tabular}{llllll}
\hline \multirow{2}{*}{ Percobaan } & \multicolumn{5}{l}{ Faktor Pengujian } \\
\cline { 2 - 5 } & $\begin{array}{l}\mathrm{A} \\
\left(\mathrm{W}_{\text {pasir }} / \mathrm{W}_{\text {pasta }}\right)\end{array}$ & $\begin{array}{l}\text { Komposisi A } \\
(\mathrm{gram})\end{array}$ & $\begin{array}{l}\mathrm{B} \\
\left(\mathrm{V}_{\text {foam }} / \mathrm{V}_{\text {pasir+pasta }}\right)\end{array}$ & $\begin{array}{l}\text { Komposisi B }(\mathrm{ml}) \\
\mathrm{C}\end{array}$ & $\begin{array}{l}\mathrm{C} \\
\text { Suhu }\left({ }^{\circ} \mathrm{C}\right)\end{array}$ \\
\hline 1 & 1 & $450^{1}, 450^{2}$ & 1 & $250^{3}$ & 25 \\
2 & 1 & $450^{1}, 450^{2}$ & 2 & $500^{3}$ & 60 \\
3 & 1 & $450^{1}, 450^{2}$ & 3 & $750^{3}$ & 100 \\
4 & 1,5 & $675^{1}, 450^{2}$ & 1 & $375^{3}$ & 60 \\
5 & 1,5 & $675^{1}, 450^{2}$ & 2 & $750^{3}$ & 100 \\
6 & 1,5 & $675^{1}, 450^{2}$ & 3 & $1125^{3}$ & 25 \\
7 & 2 & $900^{1}, 450^{2}$ & 1 & $500^{3}$ & 100 \\
8 & 2 & $900^{1}, 450^{2}$ & 2 & $1000^{3}$ & 25 \\
9 & 2 & $900^{1}, 450^{2}$ & 3 & $1500^{3}$ & 60 \\
\hline
\end{tabular}

${ }^{1}$ massa agregat halus pasir (gram).

${ }^{2}$ massa pasta geopolimer yang terdiri dari abu layang (fly ash), natrium silikat dan natrium hidroksida.

${ }^{3}$ volume foam dalam $\mathrm{mL}$.

\subsection{Sintesa Beton Ringan Geopolimer}

Tahapan pembuatan beton ringan geopolimer yang pertama adalah dengan membuat larutan $\mathrm{NaOH} 7 \mathrm{M}$ satu hari sebelum pembuatan beton. Selanjutnya menyiapkan komposisi benda uji yakni abu layang (fly ash), pasir, campuran larutan $\mathrm{NaOH}$ dan Natrium Silikat, serta foam sebelum dilakukan pencampuran. Tahap awal saat pencampuran adalah dengan mencampurkan larutan $\mathrm{NaOH}$ dan Natrium Silikat sebagai larutan alkali aktivator. Fly ash dicampur dengan larutan alkali di dalam mixer hingga membentuk pasta geopolimer. Agregat pasir kemudian dimasukkan ke dalam pasta hingga menjadi beton geopolimer. Tahap selanjutnya adalah dilakukan penambahan foam agent dengan bantuan foam generator untuk membentuk ke dalam campuran beton geopolimer. Campuran tersebut diaduk hingga gelembung udara tersebar merata dan proses pencetakan dilakukan dengan memasukkan pasta ke dalam cetakan kubus $5 \times 5 \times 5 \mathrm{~cm}^{3}$. Hasil cetakan benda uji tersebut kemudian dilepas pada batas umur 1 hari dari cetakan setelah keadaan keras hingga diperoleh benda uji ukuran $5 \times 5 \times 5 \mathrm{~cm}^{3}$ dengan toleransi ffl $0,2 \mathrm{~cm}^{3}$. Proses curing benda uji dilakukan hingga umur spesimen 28 hari seperti tertera pada Gambar 2.

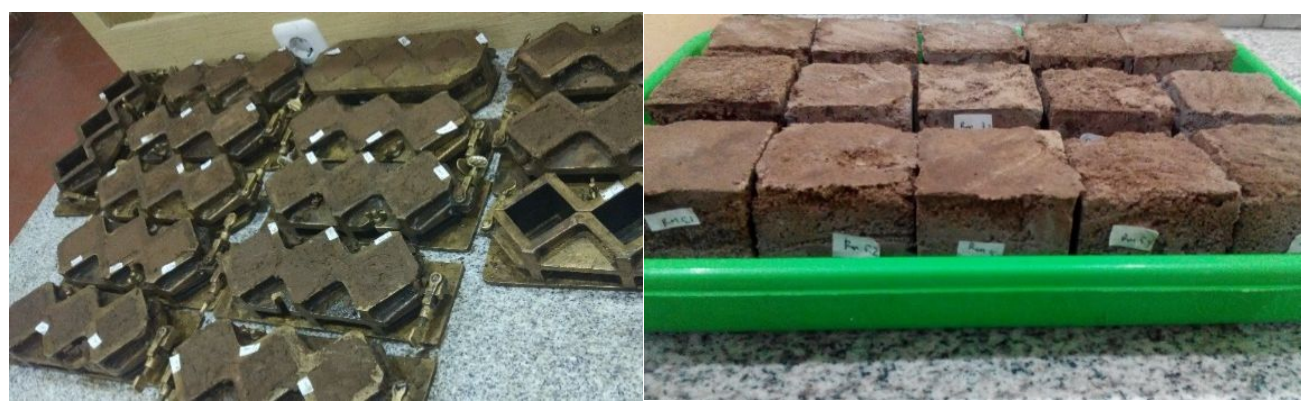

Gambar 2. Proses pencetakan dan curing benda uji beton ringan geopolimer

\subsection{Pengujian Densitas}

Pengujian densitas beton ringan dilakukan dengan mengambil benda uji berumur 28 hari. Benda uji tersebut dihitung volumenya dan ditimbang untuk mengetahui berat dari benda 
uji. Nilai volume dan berat yang tersebut digunakan untuk perhitungan densitas sesuai persamaan (1).

$$
p=\frac{m}{v}
$$

Dimana:

$$
\begin{array}{ll}
p & =\text { Massa Jenis }\left(\mathrm{Kg} / \mathrm{m}^{3}\right) \\
\mathrm{m} & =\text { Massa beton }(\mathrm{Kg}) \\
\mathrm{v} & =\operatorname{Volume} \text { beton }\left(\mathrm{m}^{3}\right)
\end{array}
$$

\subsection{Pengujian Kuat Tekan}

Pengujian kuat tekan dilakukan dengan menggunakan alat uji kuat tekan pada laboratorium fisika PT. Semen Indonesia (Persero) Tbk, Jl. Veteran Gresik. Langkah pengujian yang dilakukan yakni dengan meletakkan benda uji pada plate secara simetris dan selanjutnya mesin dijalankan untuk memberikan pembebanan pada benda uji.

\subsection{Analisa Data}

Untuk mengetahui faktor berpengaruh pada kuat tekan beton ringan geopolimer CLC digunakan Analysis of Variance (ANOVA). Selanjutnya dilakukan analisa dalam menentukan kombinasi level optimum pada setiap faktor pengujian.

\section{HASIL DAN PEMBAHASAN}

\subsection{Data Pengujian Densitas}

Nilai densitas spesimen beton ringan geopolimer berkisar antara 1,07 - 2,04 gr/cm3 seperti tertera pada Tabel 4. Berdasarkan SNI-03-3449-2002 menyatakan bahwa densitas beton ringan maksimal adalah $1,85 \mathrm{gr} / \mathrm{cm} 3$, sehingga dalam penelitian ini beberapa spesimen beton ringan geopolimer memiliki nilai rata-rata densitas yang melebihi batas, yakni pada run 1, 4, 7 dan 8 . Hal tersebut dipengaruhi besarnya penambahan pasir sebagai agregat pengisi yang menambah massa spesimen geopolimer.

Tabel 4. Hasil Perhitungan Densitas

\begin{tabular}{lccccc}
\hline \multirow{2}{*}{ Run } & \multicolumn{3}{c}{ Replikasi densitas $\left(\mathrm{gr} / \mathrm{cm}^{3}\right)$} & Densitas rata-rata \\
\cline { 2 - 5 } & Re-1 & Re-2 & Re-3 & Re-4 & (DR) \\
\hline 1 & 2,09 & 2,02 & 1,99 & 2,05 & 2,04 \\
2 & 1,50 & 1,54 & 1,51 & 1,74 & 1,57 \\
3 & 1,90 & 1,20 & 1,74 & 1,25 & 1,52 \\
4 & 1,75 & 1,82 & 1,97 & 2,02 & 1,89 \\
5 & 1,17 & 1,19 & 1,15 & 1,12 & 1,16 \\
6 & 1,44 & 1,74 & 1,74 & 1,70 & 1,66 \\
7 & 2,02 & 1,91 & 1,91 & 1,86 & 1,92 \\
8 & 1,80 & 1,78 & 1,80 & 2,05 & 1,86 \\
9 & 1,04 & 1,07 & 1,10 & 1,08 & 1,07 \\
\hline
\end{tabular}

\subsection{Data Pengujian Kuat Tekan}

Data kuat tekan digunakan pada analisa data eksperimen dalam menentukan kombinasi yang paling optimum pada penggunaan metode taguchi sehingga dapat menghasilkan kuat tekan optimum. Nilai kuat tekan dari setiap pengujian seperti tertera pada Tabel 5. 
Tabel 5. Hasil Perhitungan Kuat Tekan

\begin{tabular}{lccccc}
\hline \multirow{2}{*}{ Run } & \multicolumn{3}{c}{ Replikasi Kuat Tekan $\left(\mathbf{k g} / \mathbf{c m}^{2}\right)$} & \multirow{2}{*}{ Kuat Tekan Rata-rata } \\
\cline { 2 - 5 } & Re-1 & Re-2 & Re-3 & Re-4 & (KR) \\
\hline 1 & 9,00 & 4,80 & 5,00 & 6,40 & 6,30 \\
2 & 1,20 & 1,20 & 1,00 & 2,60 & 1,50 \\
3 & 6,00 & 0,60 & 4,60 & 1,80 & 3,25 \\
4 & 2,00 & 2,60 & 8,20 & 9,60 & 5,60 \\
5 & 0,20 & 0,40 & 0,60 & 0,20 & 0,35 \\
6 & 0,20 & 1,40 & 2,00 & 1,20 & 1,20 \\
7 & 8,80 & 4,00 & 3,00 & 3,20 & 4,75 \\
8 & 1,80 & 1,20 & 1,60 & 3,00 & 1,90 \\
9 & 0,20 & 0,20 & 0,20 & 0,20 & 0,20 \\
\hline
\end{tabular}

\subsection{Pengolahan dan Analisa Data}

\subsubsection{Uji Normalitas}

Untuk pengujian normalitas pada data kuat tekan diberikan hipotesa sebagai berikut:

Ho : Data sampel uji kuat tekan beton ringan geopolimer berdistribusi normal

H1 : Data sampel uji kuat tekan beton ringan geopolimer tidak berdistribusi normal

Hipotesa awal (Ho) akan diterima jika nilai dari P-Value >0,05.

Tabel 6. Uji Normalitas

\begin{tabular}{|c|c|c|}
\hline & & Data Kuat Tekan \\
\hline $\mathrm{N}$ & & 36 \\
\hline \multirow[t]{2}{*}{ Normal Parameters ${ }^{\mathrm{a}}$} & Mean & 27,8333 \\
\hline & Std. Deviation & 27,76380 \\
\hline Asymp. Sig. (2-tailed) & & 0,132 \\
\hline
\end{tabular}

a. Test distribution is Normal.

Uji normalitas menunjukkan bahwa nilai dari P-Value sebesar $0,132>$ alfa $(\alpha=0,05)$. Artinya dari data uji kuat tekan tersebut berdistribusi normal.

\subsubsection{Penentuan Faktor Berpengaruh dengan ANOVA}

Hipotesa pada uji ANOVA yang diberikan untuk mengetahui pengaruh dari setiap faktor dapat dinotasikan sebagai berikut:

Ho : Faktor tidak berpengaruh signifikan terhadap kuat tekan beton ringan

H1 : Faktor berpengaruh signifikan terhadap kuat tekan beton ringan

Ho akan ditolak jika nilai $\mathrm{F}$ hitung $>\mathrm{F}$ tabel. 
Tabel 7. Hasil ANOVA

\begin{tabular}{lcccrr}
\hline \multicolumn{6}{l}{ Analysis of Variance for R,using Adjusted SS for Tests } \\
\hline Source & DF & Seq SS & Adj SS & Adj MS & F-hitung \\
A & 2 & 376,2 & 376,2 & 188,1 & 1,24 \\
B & 2 & 3482,9 & 3482,9 & 1741,4 & 11,45 \\
C & 2 & 80,7 & 80,7 & 40,4 & 0,27 \\
Error & 2 & 304,2 & 304,2 & 152,1 & \\
Total & 8 & 4244,1 & & & \\
\hline
\end{tabular}

Analisis pengaruh pasir (agregat halus), jumlah foam serta suhu curing dilakukan secara kuantitatif dengan membandingkan nilai $\mathrm{F}$ hitung dengan $\mathrm{F}$ tabel, sehingga diperoleh penolakan atau penerimaan hipotesa yang telah dirumuskan. Dengan membandingkan kedua nilai tersebut, dapat diketahui signifikasi variabel penelitian dalam menghasilkan kuat tekan pada beton ringan selular geopolimer. Hasil ANOVA faktor A (perbandingan berat pasir terhadap pasta geopolimer) mendapatkan nilai F-hitung sebesar 1,24. Nilai tersebut lebih kecil dibandingkan dengan nilai $\mathrm{F}$ tabel $(3,28)$. Hal tersebut menunjukkan bahwa Ho diterima pada faktor A, artinya perbandingan pasir terhadap pasta geopolimer tidak berpengaruh signifikan terhadap nilai kuat tekan beton ringan geopolimer. Hasil ini sama dengan penelitian yang telah dilakukan oleh U. Anggarini, Kosada, and Sukmana (2017) yang menunjukkan bahwa penggunaan agregat tidak berpengaruh signifikan terhadap kuat tekan beton geopolimer.

Faktor B (perbandingan volume antara foam terhadap campuran pasir dan pasta geopolimer) mendapatkan nilai F-hitung $11,45>$ nilai $\mathrm{F}$ tabel $(3,28)$ sehingga faktor $\mathrm{B}$ berpengaruh signifikan terhadap kuat tekan pada variasi eksperimen yang telah dilakukan. Abdullah et al. (2014) menyatakan bahwa penambahan foam akan menyebabkan menurunnya kekuatan bata ringan, hal ini disebabkan oleh semakin banyaknya rongga udara yang terbebntuk dalam beton akibat penambahan foam.

Faktor $\mathrm{C}$ (temperatur curing) nilai $\mathrm{F}$ hitungnya sebesar $0,27<\mathrm{F}$ tabel $(3,28)$ sehingga menerima Ho dan tidak memiliki pengaruh terhadap kuat tekan pada beton geopolimer yang dihasilkan. Temperatur curing yang semakin tinggi dapat menurunkan densitas bata ringan (Susanti, 2015), namun dalam penelitian ini penurunan densitas beton tidak menurunkan kuat tekan secara signifikan.

\subsubsection{Penentuan Kombinasi Level Faktor Optimum}

Kombinasi level yang optimum pada setiap faktor ditentukan dengan menggunakan nilai SNR "large is better" sehingga dipilih nilai kuat tekan yang paling besar dari eksperimen yang telah dilakukan. Penentuan kombinasi ini dilakukan untuk mengetahui pada level berapa setiap faktor memiliki nilai optimum untuk menghasilkan nilai kuat tekan yang paling baik. Hasil dari kombinasi bisa berada pada salah satu dari 9 variasi run yang telah ditentukan dengan OA, namun tidak menutup kemungkinan bahwa kombinasi level faktor terdapat diluar variasi yang telah ditentukan.

Perhitungan untuk menentukan nilai kombinasi level optimum pada setiap faktor dapat diperoleh dari penggunaan nilai SNR dari setiap run. Nilai SNR dapat diperoleh dengan cara sebagai berikut: 
Contoh penentuan SNR (large is better) pada run 1 :

1. $\mathrm{SNR}=-10 \log _{10}\left[\frac{1}{n} \sum_{i=1}^{n} \frac{1}{y i^{2}}\right]$

2. $\mathrm{SNR}=-10 \log _{10}\left[\frac{1}{4} \sum_{i=1}^{n} \frac{1}{90^{2}}+\frac{1}{48^{2}}+\frac{1}{50^{2}}+\frac{1}{64^{2}}\right]$

3. $\mathrm{SNR}=35,99$

Nilai SNR pada setiap run dapat dilihat pada Tabel 8. Hasil SNR pada tabel tersebut digunakan dalam menentukan nilai kombinasi pada level di setiap faktor penelitian.

Tabel 8. Hasil Perhitungan Kuat Tekan Rata-rata (KR) dan SNR Setiap Run

\begin{tabular}{|c|c|c|c|c|c|c|c|c|c|}
\hline \multirow{2}{*}{ Run } & \multicolumn{3}{|c|}{ Faktor } & \multicolumn{4}{|c|}{ Replikasi Kuat Tekan $\left(\mathrm{kg} / \mathrm{cm}^{2}\right)$} & \multirow{2}{*}{$\begin{array}{l}\mathrm{KR} \\
\left(\mathrm{Kg} / \mathrm{cm}^{2}\right)\end{array}$} & \multirow{2}{*}{ SNR } \\
\hline & $\mathbf{A}$ & B & C & Re-1 & Re-2 & Re-3 & Re-4 & & \\
\hline 1 & $\mathrm{~A} 1$ & B1 & $\mathrm{C} 1$ & 90 & 48 & 50 & 64 & 63,00 & 35,99 \\
\hline 2 & $\mathrm{~A} 1$ & B2 & $\mathrm{C} 2$ & 12 & 12 & 10 & 26 & 15,00 & 23,52 \\
\hline 3 & $\mathrm{~A} 1$ & B3 & C3 & 60 & 6 & 46 & 18 & 32,50 & 30,24 \\
\hline 4 & A2 & B1 & $\mathrm{C} 2$ & 20 & 26 & 82 & 96 & 56,00 & 34,96 \\
\hline 5 & $\mathrm{~A} 2$ & B2 & C3 & 2 & 4 & 6 & 2 & 3,50 & 10,88 \\
\hline 6 & $\mathrm{~A} 2$ & B3 & $\mathrm{C} 1$ & 2 & 14 & 20 & 12 & 12,00 & 21,58 \\
\hline 7 & A3 & B1 & C3 & 88 & 40 & 30 & 32 & 47,50 & 33,53 \\
\hline 8 & A3 & B2 & $\mathrm{C} 1$ & 18 & 12 & 16 & 30 & 19,00 & 25,58 \\
\hline \multirow[t]{2}{*}{9} & A3 & B3 & $\mathrm{C} 2$ & 2 & 2 & 2 & 2 & 2,00 & 6,02 \\
\hline & & & & & & & Rata-rata & 27,83 & 24,70 \\
\hline
\end{tabular}

Tahapan pertama yang dilakukan adalah dengan menghitung rata-rata SNR pada setiap level 1, 2 dan 3. Perhitugan nilai SNR rata-rata pada level di setiap faktor juga menggunakan cara yang sama dengan perhitungan nilai kuat tekan rata-rata pada setiap level. Nilai SNR rata-rata untuk level 1 pada faktor A dapat dilihat sebagai berikut:

SNR rata-rata pada level 1 faktor A :

$$
\begin{aligned}
& \operatorname{SNR} A_{1}=\frac{\text { SNR1 }+ \text { SNR2 }+ \text { SNR3 }}{3} \\
& \operatorname{SNR} A_{1}=\frac{35,99+23,52+30,24}{3} \\
& \operatorname{SNR} A_{1}=29,92
\end{aligned}
$$

Hasil perhitungan untuk SNR rata-rata setiap level di masing-masing faktor tersebut dapat dilihat lebih lengkap pada Tabel 9 sebagai berikut: 
Tabel 9. Nilai SNR Rata-rata untuk Masing-masing Level

\begin{tabular}{lccc}
\hline \multirow{2}{*}{ Level } & \multicolumn{3}{c}{ Faktor } \\
\cline { 2 - 4 } & $\mathrm{A}$ & $\mathrm{B}$ & $\mathrm{C}$ \\
\hline 1 & 29,92 & 34,83 & 27,72 \\
2 & 22,48 & 19,99 & 21,50 \\
3 & 21,71 & 19,28 & 24,88 \\
\hline
\end{tabular}

Hasil dari perhitungan pada tabel tersebut juga digambarkan pada grafik plot untuk melihat nilai dari level yang paling tinggi pada setiap faktor pengujian sebagai berikut:

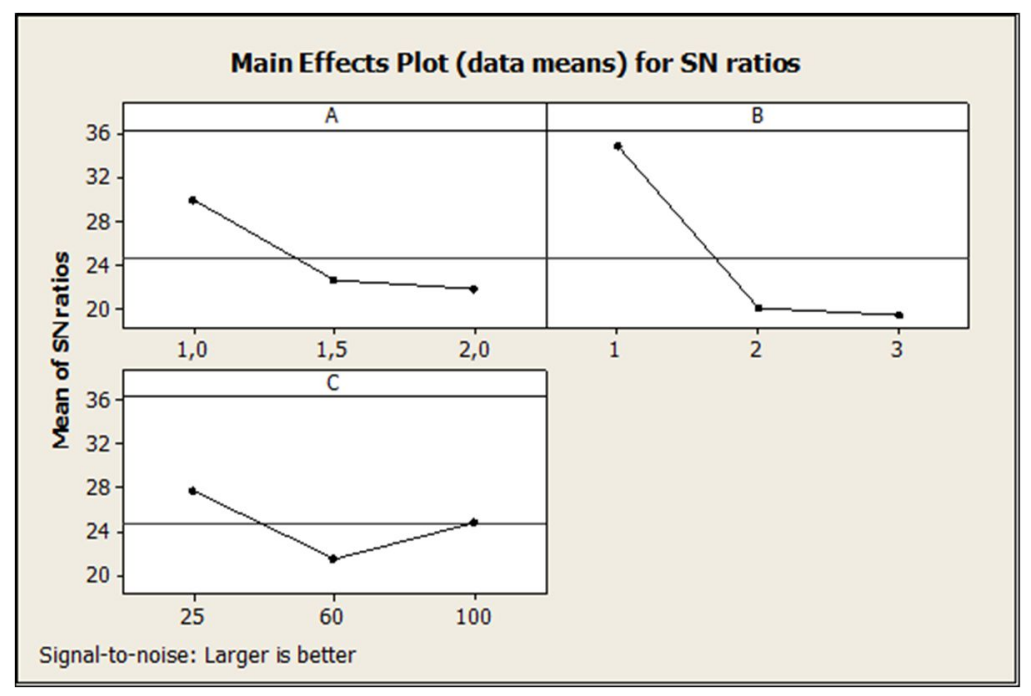

Gambar 3. Grafik Respon SNR Rata-rata Setiap Level

Nilai rata-rata SNR paling besar dari setiap faktor digunakan dalam menentukan kombinasi level yang menghasilkan kuat tekan paling optimum. Berdasarkan Table 9 dan Gambar 3 tersebut Faktor A optimum pada level 1, hal ini menunjukkan bahwa penggunaan pasir yang paling optimum pada penelitian ini adalah yang menggunakan rasio perbandingan berat pasir terhadap pasta geopolimer sebesar 1:1. Grafik pada faktor A menjelaskan bahwa semakin tinggi level (semakin banyak pasir) yang digunakan akan membuat nilai kuat tekan semakin turun pada beton ringan geopolimer CLC. Hal tersebut dapat terjadi karena semakin banyak agregat atau semakin banyak komposisi yang digunakan melebihi kadar normal dapat membuat adonan tidak optimal dan menurunkan kekuatannya (Sukiyaningrum, 2017).

Nilai SNR masing-masing level pada faktor B juga menunjukkan bahwa perbandingan volume antara foam terhadap campuran pasir dan pasta geopolimer yang paling optimum adalah 1:1. Semakin tinggi level (semakin banyak perbandingan foam yang digunakan) pada penelitian dapat menyebabkan struktur beton ringan semakin rapuh. Kondisi tersebut akan membuat kuat tekan beton ringan menjadi rendah namun memiliki densitas yang lebih ringan. Semakin banyak foam yang digunakan dapat membuat kerusakan pada struktur beton sehingga nilai kuat tekannya sangat rendah (Susanto, Widjaja, Antoni, \& Hardjito, 2015).

Level tertinggi pada faktor C juga terdapat pada level 1 yang menunjukkan bahwa suhu optimum untuk menghasilkan kuat tekan optimum pada beton ringan geopolimer berbasis CLC ini adalah pada suhu $25{ }^{\circ} \mathrm{C}$. Jika dilihat dari Gambar 3, dapat dijelaskan bahwa nilai 
kuat tekan tidak begitu meningkat pada saat level temperatur semakin tinggi. Kuat tekan pada temperatur $60{ }^{\circ} \mathrm{C}$ menghasilkan nilai yang paling rendah. Nilai kuat tekan tersebut naik saat temperatur diberikan pada suhu $100{ }^{\circ} \mathrm{C}$, namun kondisi tersebut masih kurang baik jika dibandingan pada temperatur ruang yang menghasilkan nilai kuat tekan maksimum. Pada penelitian yang dilakukan Susanti (2015) terkait penggunaan curing pada beton ringan geopolimer memberikan pernyataan bahwa semakin besar suhu yang diberikan saat curing dapat mengurangi densitas dari beton. Nilai densitas saat suhu ruang lebih besar dibandingkan dengan densitas beton saat dilakukan curing pada suhu $60^{\circ} \mathrm{C}$. Nilai tersebut juga dapat berpengaruh pada nilai kuat tekan sehingga dapat menjadi lebih besar. Kondisi mekanisme reaksi yang berbeda pada proses curing akan menghasilkan sifat yang berbeda juga pada sifat akhir geopolimer (Ferdy, 2010).

Hasil perhitungan SNR menunjukan bahwa kombinasi optimum dari penelitian terdapat pada variasi yang telah ditentukan oleh OA. Kombinasi tersebut merupakan variasi antara faktor dan level yang paling optimal sehingga dalam penelitian ini tidak perlu melakukan analisa prediksi nilai kuat tekan maksimum dan konfirmasi eksperimen lanjutan. Nilai kuat tekan optimum tersebut berada pada run 1 eksperimen dengan nilai rata-rata kuat tekan pada eksperimen sebesar $63 \mathrm{~kg} / \mathrm{cm}^{2}$ dan densitas sebesar $2,036 \mathrm{~g} / \mathrm{cm}^{3}$. Nilai densitas tersebut masih belum termasuk ke dalam kategori beton ringan SNI-03-3449-2002 namun masih tetap bisa digunakan untuk beton insulasi. Hasil penelitian ini diharapkan dapat memberikan suatu inovasi pada diversifikasi pengembangan material beton non kalsium. Beton ringan geopolimer disintesis pada suhu kamar dengan memanfaatkan limbah hasil pembakaran batu bara berupa abu layang, sehingga dapat berpotensi mengurangi emisi gas $\mathrm{CO}_{2}$ sebagai salah satu gas penyebab pemanasan global serta mengurangi penumpukan limbah abu layang. Pengembangan material geopolimer lebih lanjut diperlukan untuk menghasilkan material ringan dengan kualitas yang memenuhi standar SNI.

\section{KESIMPULAN}

Faktor yang memiliki pengaruh signifikan terhadap kuat tekan beton geopolimer berbasis CLC adalah perbandingan volume antara foam terhadap campuran pasir dan pasta geopolimer. Komposisi optimal diperoleh menggunakan kombinasi perbandingan berat pasir dengan pasta geopolimer sebesar 1:1, perbandingan volume antara foam terhadap campuran pasir dan pasta geopolimer sebesar 1:1 serta penggunaan temperatur curing sebesar $25^{\circ} \mathrm{C}$. Sehingga menghasilkan kuat tekan rata-rata sebesar $63 \mathrm{~kg} / \mathrm{cm}^{2}$. Penggunaan foam agent dalam sintesa beton ringan geopolimer menghadapi kendala dalam proses pembentukan struktur berpori yang harus dilangsungkan secara cepat. Sehingga pada penelitian selanjutnya peneliti menyarankan untuk menggunakan jenis pengembang lain seperti Alumunium powder serta melakukan variasi pada penggunaan agregat sehingga dapat diketahui pengaruh dari setiap jenis agregat pada penelitian yang dilakukan. Selain itu, peneliti juga menyarankan untuk membuat faktor baru terkait variasi waktu pengerjaan dan variasi pencampuran bahan uji. Hal tersebut bertujuan untuk mengetahui pengaruh dari proses pembuatan terhadap nilai kuat tekan dan densitas. Peneliti juga menyarankan untuk menambah durasi curing sehingga dapat diketahui apakah terdapat perbedaan antara lama proses curing yang dilakukan terhadap densitas dan kuat tekan beton ringan geopolimer. 


\section{DAFTAR PUSTAKA}

Abdullah, M. M. A. B., Yahya, Z., Tahir, M. F. M., Hussin, K., Binhussain, M., \& Sandhu, A. V. (2014). Fly Ash Based Lightweight Geopolymer Concrete Using Foaming Agent Technology. International Journal of: Applied Mechanics and Materials, 679, 20-24.

Anggarini, U., Kosada, C., \& Sukmana, N. C. (2017). Penerapan Metode Taguchi pada Perancangan Eksperimen Beton Geopolimer Berbasis Abu Layang.

Anggarini, U., \& Sukmana, N. C. (2018). Investigating Alumina silicate Source in Geopolymer Compressive Strength: Surface Morphology and Crystal Phase Study.

Anggarini, U., Sukmana, N. C., \& Prasetya, F. A. (2017). Synthesis and Characterization of Fly Ash Geopolymer for Water Absorbent Material. MATEC Web of Conferences, 97.

Bhakti, M. H., Olivia, M., \& Kamaldi, A. (2015). Agregat Buatan Geopolimer dengan Bahan Dasar Abu Terbang (Fly Ash) dan Abu Sawit (Palm Oil Fuel Ash). Jom FTEKNIK, O2(02).

Darmawan, A. (2015). Perkembangan Penyediaan dan Pemanfaatan Migas Batubara Energi Baru Terbarukan dan Listrik Edisi Ke-1. Jakarta: Pusat Data dan Teknologi Informasi Energi dan Sumber Daya Mineral Kementerian Energi dan Sumber Daya Mineral.

Ferdy. (2010). Pengaruh Temperatur dan Waktu Curing terhadap Kuat Tekan Pasta Geopolimer Berbahan Dasar Abu Terbang. (S1), Universitas Indonesia, Depok.

Narayan, N., \& Ramamurthy, K. (2000). Structure and Properties of Aerated Concrete: A Review. Jurnal Cement \& Composite, 22, 321-329.

Ramdani, D. (2015). Industry Update: Kontruksi Vol. O6. Jakarta: Office of Chief Ecnomist PT Bank Mandiri (persero) Tbk.

Sukiyaningrum, S. M. (2017). Analisis Kuat Tekan Beton Menggunakan Kombinasi Pasir Merah Purwodadi dan Pasir Kaliworo Klaten dengan Bahan Tambahan Tetes Tebu. (S1), Universitas Muhammadiyah Surakarta, Surakarta.

Susanti. (2015). Pengembangan Geopolimer Berbasis Abu Terbang (Fly Ash) untuk Aplikasi Beton Ringan Ramah Lingkungan (Green Light Concrete). Prosiding Pertemuan Ilmiah XXIX HFI, Yogyakarta, 280-283.

Susanto, F. E., Widjaja, A. A., Antoni, \& Hardjito, D. (2015). Pembuatan Pasta Ringan Geopolimer Celluler Lightweight Concrete (CLC) Berbasis Campuran Lumpur Sidoarjo dan Fly Ash. Jurnal Dimensi Pratama Tenik Sipil, o2(04).

Wijaya, Y. P. (2014). Paving Geopolimer Dari Coal Ash Limbah Pabrik. Prosiding Seminar Nasional Aplikasi Teknologi Prasarana Wilayah (ATPW), 33-42.

Wuryandari, T. (2009). Metode Taguchi untuk Optimalisasi Produk pada Rancangan Faktorial. Jurnal Media Statistika, O2(02), 81-92. 